\title{
ПОДДЕРЖАНИЕ МУЛЬТИПОТЕНТНЫХ МЕЗЕНХИМНЫХ СТВОЛОВЫХ КЛЕТОК СЕЛЬСКОХОЗЯЙСТВЕННЫХ ЖИВОТНЫХ В КРИОГЕЛЯХ НА ОСНОВЕ ПОЛИМЕРОВ ПРИРОДНОГО ПРОИСХОЖДЕНИЯ
}

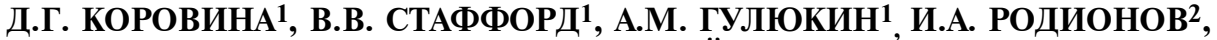 \\ В.К. КУЛАКОВА ${ }^{2}$, В.И. ЛОЗИНСКИЙ 2 , И.П. САВЧЕНКОВА'
}

Мультипотентные мезенхимные стволовые клетки (ММСК) сельскохозяйственных животных, рост которых в культуре определяется прикрепленностью к твердому субстрату, - перспективный клеточный материал для ветеринарной медицины, биотехнологии, вирусологии. Один из методов преодоления клеточной адгезии в суспензионных биореакторах с целью получения большого количества клеток с постоянными показателями приемлемого качества - использование пористых носителей, сформированных из полимеров природного происхождения. Мы впервые представляем данные, которые позволяют обосновать параметры культивирования адгезивных культур животных ММСК с использованием объемных криогелевых носителей на белковой основе для последующего суспензионного культивирования полученных конструкций. Целью работы было изучение возможности культивирования ММСК сельскохозяйственных животных в трехмерных губчатых матрицах, представляющих собой криогели на основе желатина, суммарного белка плазмы крови и сыворотки крови плодов крупного рогатого скота (КРС). В качестве биологического объекта использовали ММСК, выделенные из костного мозга (КМ) и жировой ткани (ЖТ) КРС и КМ овцы, а также мышиные фибробласты линии STO. Пористыми носителями для культивирования клеток служили криогели на основе желатина, а также суммарного белка плазмы или сыворотки крови КРС. Установлена оптимальная концентрация клеток для заселения клеточной суспензии методом естественного всасывания при набухании отжатых губок объемом 0,24 см$^{3}-1,0 \times 10^{6}$ клеток в 100 мкл среды в течение 2 ч насыщения. Эффективность загрузки ММСК в губчатые носители составляла $98 \%$. Анализ гистологических срезов (не менее 10 для каждого образца) трех криогелей продемонстрировал способность всех трехмерных пористых носителей поддерживать клетки в культуре на протяжении 14 сут. Губки были заполнены клетками, которые сохраняли морфологию и размножались в местах прикрепления к полимерной поверхности. Все клетки мигрировали из монослоя в объеме криогеля с нижней стороны и не обнаруживались на верхних сторонах исследуемых криогелей. На 10-е сут культивирования было выявлено распространение фибробластов линии STO в объеме губчатых носителей на основе желатина, белка плазмы крови и сыворотки крови плодов коров (CKПК) («GE Healthcare», США) на расстояние соответственно 2990, 2871 и 1930 мкм. ММСК, выделенные из ЖТ КРС, мигрировали вглубь пористой структуры губчатых матриц соответственно на 607, 1364 и 657 мкм. Распространение ММСК, выделенных из КМ КРС и овец, в криогелях на основе разных материалов, существенно не отличалось от степени миграции ММСК ЖТ. Способность ММСК сельскохозяйственных животных на ранних (2-3-й) и поздних (9-10-й) пассажах культивирования прикрепляться к макропористым криогелям существенно не различалась. Сравнительный анализ полученных результатов в трех повторных экспериментах продемонстрировал, что макропористые матрицы на основе желатина, белков плазмы крови КРС и СКПК поддерживают жизнеспособность ММСК в течение краткосрочного культивирования, способствуют клеточной адгезии, пролиферации и миграции. Полученные данные позволяют прогнозировать использование этих криогелей в качестве матриц для ММСК, полученных от сельскохозяйственных животных, для исследовательских и прикладных целей.

Ключевые слова: мультипотентные мезенхимные стволовые клетки, жировая ткань, костный мозг, сельскохозяйственные животные, адгезия, миграция, жизнеспособность, криогели, желатин, макропористые губки, белки плазмы и сыворотки крови крупного рогатого скота.

Мультипотентные мезенхимные стволовые клетки (ММСК), обладающие способностью к самообновлению и потенциями к дифференцировке in vitro в адипо-, остео- и хондрогенном направлениях, - перспективный материал для ветеринарии, клеточной и тканевой инженерии, вирусологии или скрининга лекарственных препаратов $(1,2)$. Основопола-

\footnotetext{
* Работа выполнена в рамках НИР № 0578-2018-0006 «Создание новых клеточных систем с заданными свойствами на основе стволовых клеток млекопитающих, в том числе сельскохозяйственных животных для ветеринарии, вирусологии и биотехнологии».
}

1214 
гающий критерий, необходимый для использования потенциала MMCK, способность воспроизводимо получать достаточное количество клеток неизменно высокого качества с наименьшими затратами. К популярным методам культивирования ММСК относится адгезивная культура в присутствии сыворотки. Адгезивные методы, используемые в настоящее время, не могут обеспечить подходящую систему культивирования из-за разнородных статических условий, что приводит к изменению качества клеток от партии к партии, трудоемкой методологии, а также получению строго определенного количества клеток из-за лимитированной площади поверхности для их роста и, соответственно, к ограничениям в масштабируемости (3-5). Один из методов преодоления клеточной адгезии в суспензионных биореакторах - использование микроносителей для культивирования (68). Такие системы нуждаются в усовершенствовании матриц и адаптации параметров культивирования клеток (9).

Пористые гели рассматриваются как перспективный материал для создания носителей (матриц) при культивировании клеток благодаря их способности моделировать основные свойства большинства мягких тканей. Полимерные цепочки, соединенные поперечными связями, содержат большое количество воды, облегчают транспорт кислорода, питательных веществ и продуктов метаболизма, а также растворимых факторов. Многие гели могут формироваться в условиях, благоприятных для живых клеток, и легко модифицироваться для придания нужных физико-механических свойств и скорости деградации. Использование природных биополимеров в создании биоинженерных каркасов позволяет наиболее точно имитировать структуру, свойства тканей и органов, а также воспроизводить микроокружение со строением, близким к структуре природных клеточных ниш. Это предоставляет возможность достигать оптимального заселения искусственных ниш ММСК и способствует их практически полной дифференцировке в нужные типы клеток (10).

При создании биоинженерных конструкций необходимо, чтобы поры внутри трехмерного носителя были взаимосвязаны, имели размеры, оптимальные для инокуляции клеток, и обладали достаточной площадью для их последующего роста. Этим требованиям отвечают макропористые криогели, образование которых осуществляется в неглубоко замороженной среде (11). Им присущи некоторые специфические особенности по сравнению с обычными гелями, формируемыми при температурах выше точки кристаллизации растворителя. Для криогелей характерна макропористость, причем макропоры взаимосвязаны $(12,13)$. В зависимости от начальной концентрации предшественников, а также их свойств и режимов криогенной обработки можно получать макропористые матрицы с порами сечением от десятых долей до 10 мкм и сверхмакропористые (губчатые) системы с порами, размер которых составляет десятки и сотни микрометров. Криогели, изготовленные из материалов природного происхождения, которые служат компонентами внеклеточного матрикса (BКМ), например коллаген, желатин и др., представляют особый интерес (14-17).

В серии экспериментов было продемонстрировано, что криогели на белковой основе (сывороточный альбумин, суммарный белок сыворотки крови) благодаря макропористой морфологии могут быть использованы в качестве пористых подложек для культивирования клеток $(18,19)$. Основными критериями биологически совместимой матрицы должны быть отсутствие цитотоксичности, поддержание адгезии, миграции, пролиферации или дифференцировки помещенных на ее поверхность клеток (20-22), а также оптимальная для дальнейшего применения механическая проч- 
ность и биорезорбируемость (23).

В настоящем сообщении мы впервые представляем данные, которые позволяют обосновать параметры культивирования адгезивных культур животных ММСК с использованием объемных криогелевых носителей на белковой основе для последующего суспензионного культивирования полученных конструкций в биореакторе.

Цель работы заключалась в изучении возможности культивирования мультипотентных мезенхимных стволовых клеток сельскохозяйственных животных в трехмерных губчатых матрицах - криогелях на основе желатина, суммарного белка плазмы крови и сыворотки крови плодов крупного рогатого скота.

Методика. При выполнении экспериментов (2016-2019 годы) использовали ММСК, выделенные из костного мозга (КМ) и жировой ткани (ЖТ) крупного рогатого скота (КРС), полученные и охарактеризованные нами ранее (24), из КМ овцы (25), а также мышиные фибробласты линии STO.

Для культивирования клеток применяли материалы и реагенты компании «ПанЭко» (Россия). MMCK культивировали в среде DMEM с низкой (1 г/л) концентрацией глюкозы, 10 \% сыворотки крови плодов коров $(\mathrm{CKПК)} \mathrm{(«GE} \mathrm{Healthcare»,} \mathrm{США)} \mathrm{и} \mathrm{растворами}(\times 1)$ заменимых аминокислот и антибиотиков. Фибробласты линии STO культивировали в питательной среде DMEM с содержанием глюкозы 4 г/л, 10 \% СKПК, 2 мМ L-глутамином; конечная концентрация стрептомицина 50 мкг/мл, пенициллина - 50 ед/мл. Клетки культивировали при температуре $37{ }^{\circ} \mathrm{C}$ в увлажненной атмосфере $5 \% \mathrm{CO}_{2}$. Для длительного культивирования ММСК пассировали при плотности $5 \times 10^{3}$ кл/см².

В качестве пористых носителей для культивирования клеток использовали полученные согласно ранее опубликованным методикам криогели на основе желатина (26), а также суммарного белка плазмы или сыворотки крови КРС $(27,28)$.

Перед использованием матрицы стерилизовали. Для этого образцы помещали в лунки стерильного 24-луночного планшета («Nunc», Дания) и покрывали их этиловым спиртом на 1 ч. Спирт декантировали, а образцы трижды промывали раствором Хенкса, добавляя по 2 мл в каждую лунку. Затем в планшет вносили по 1,5 мл среды DMEM и инкубировали в термостате в течение ночи для полного удаления этилового спирта. Перед внесением клеток криогель отжимали пинцетом, и 100 мкл клеточной суспензии, содержащей $1 \times 10^{6}$ клеток, наносили на верхнюю поверхность отжатой матрицы. Из-за быстрого набухания материала губки суспензия клеток капиллярными силами втягивалась во внутреннее пространство пор, заполняя объем носителя. Губки насыщались клетками в течение 2 ч в чашке Петри, препятствующей адгезии клеток к пластику, при температуре $37{ }^{\circ} \mathrm{C}$ в $\mathrm{CO}_{2}$-инкубаторе, после чего их переносили в пробирки объемом 50 мл, которые имитировали мини-биореактор, с необработанной поверхностью и газонепроницаемыми крышками.

Адгезивную способность ММСК КРС и овцы по отношению к поверхности пор полимерных носителей оценивали подсчетом неприкрепившихся клеток. Эффективность заселения клеток в объемные криогелевые носители определяли как разность между числом клеток в исходной суспензии и их количеством после введения, отнесенную к исходному числу клеток.

Экспресс-анализ локализации заселенных в трехмерные матрицы жизнеспособных клеток проводили, используя краситель флуоресцеиндиа- 
цетат (ФД) («Thermo Fisher Scientific», США). Для этого в культуральную среду добавляли ФД в конечной концентрации 25 мкг/мл и инкубировали 5 мин при $37{ }^{\circ} \mathrm{C}$. Затем губки с клетками промывали средой без сыворотки и просматривали при помощи флуоресцентного микроскопа («Carl Zeiss», Германия) при длине волны возбуждения флуоресценции $\lambda=450$ нм и с запирающим фильтром G 247.

Для изучения способностей клеточной миграции MMCK и STO рассевали в 24-луночные планшеты и выращивали до формирования ими монослоя. Квадратные кусочки криогеля размером $10 \times 10$ мм, вырезанные в асептических условиях и промытые DMEM, слегка придавливая, размещали на поверхности монослоя клеток и культивировали в стандартных условиях $\mathrm{CO}_{2}$-инкубатора в течение 10 сут. Далее криогели промывали фосфатно-солевом буфере Дюльбекко с ионами $\mathrm{Ca}^{2+}$ и $\mathrm{Mg}^{2+}$ (ФСБ-1) и фиксировали в растворе $4 \%$ параформальдегида в ФСБ-1. Анализировали не менее 10 областей с нижней и верхней сторон криогеля, а также поперечные срезы исследуемых матриц.

Анализ клеток в трехмерных носителях выполняли с помощью стандартных методик, применяемых для гистологических исследований (29). Для приготовления срезов использовали криотом Mikrom HM 525 («Thermo Scientific», Германия), для закрепления объекта на столике криотома - заливочную среду Neg-50 («Thermo Fisher Scientific», США). Объекты замораживали при температуре $-15 \ldots-22{ }^{\circ} \mathrm{C}$ в течение 30-40 мин и затем, используя одноразовые лезвия Microm Sec35e («Thermo Fisher Scientific», США), изготавливали срезы толщиной 10-20 мкм. Срезы переносили на предметные стекла Surgipath X-tra Adhesive с адгезивным покрытием («Leica Biosystems», Германия). Сразу после просушки их фиксировали метиловым спиртом, промывали, окрашивали гематоксилином и эозином или красителем Гимза («ПанЭко», Россия) согласно инструкциям производителя. После просветления в ксилоле окрашенные препараты заключали в монтирующую среду. Морфологический анализ проводили визуально с помощью фазово-контрастного микроскопа Axio Observer D.1 («Carl Zeiss», Германия), используя для измерений программное обеспечение AxioVision Rel. 4.8 («Carl Zeiss», Германия).

Статистическую обработку данных осуществляли с помощью программы GraphPad Prism («GraphPad Software», США). В таблицах представлены средние арифметические значения $(M)$ и их стандартные ошибки $( \pm \mathrm{SEM})$. Достоверность различий оценивали по $t$-критерию Стьюдента при $\mathrm{p}<0,05$.

Результаты. Макропористые криогели (губки) на основе коммерческого желатина типа А представляли собой бело-прозрачные круглые диски диаметром 2,2-3,5 см и толщиной 0,2-0,7 см (см. рис. 1, А) с размером пор от 50 до 100 мкм. Криогели, полученные из суммарного белка плазмы крови КРС и СКПК, имели схожую друг с другом цилиндрическую форму с диаметром 1 см и толщиной 0,6-1 см (см. рис. 1, Б, В).

Криогели имеют систему разветвленных взаимосвязанных пор размером от 20 до 200 мкм, которые образуются в результате формирования кристаллов льда в замороженной среде (11). При выполнении работы было установлено, что для гистологического анализа распределения клеток в криогелях лучше выполнять срезы толщиной 10 мкм при температуре $-20 \ldots-22{ }^{\circ} \mathrm{C}$. При большей пористости губки для более комфортной визуализации подходит толщина 20 мкм.

Гистологический анализ срезов криогелей выявил макропористую структуру исследуемых матриц, их прочность и стабильность при длитель- 
ном культивировании в $\mathrm{CO}_{2}$-инкубаторе (см. рис. 1, Г-Е). Губки на основе желатина имели взаимосвязанные крупные (80-130 мкм) поры. Отличительным свойством таких матриц было градиентное изменение размеров пор от периферии вглубь материала в результате формирования кристаллов льда при замерзании исходного раствора биополимера. Матрицы на основе суммарного белка плазмы крови КРС и СКПК также имели макропористую структуру с диаметром пор 70-170 мкм.

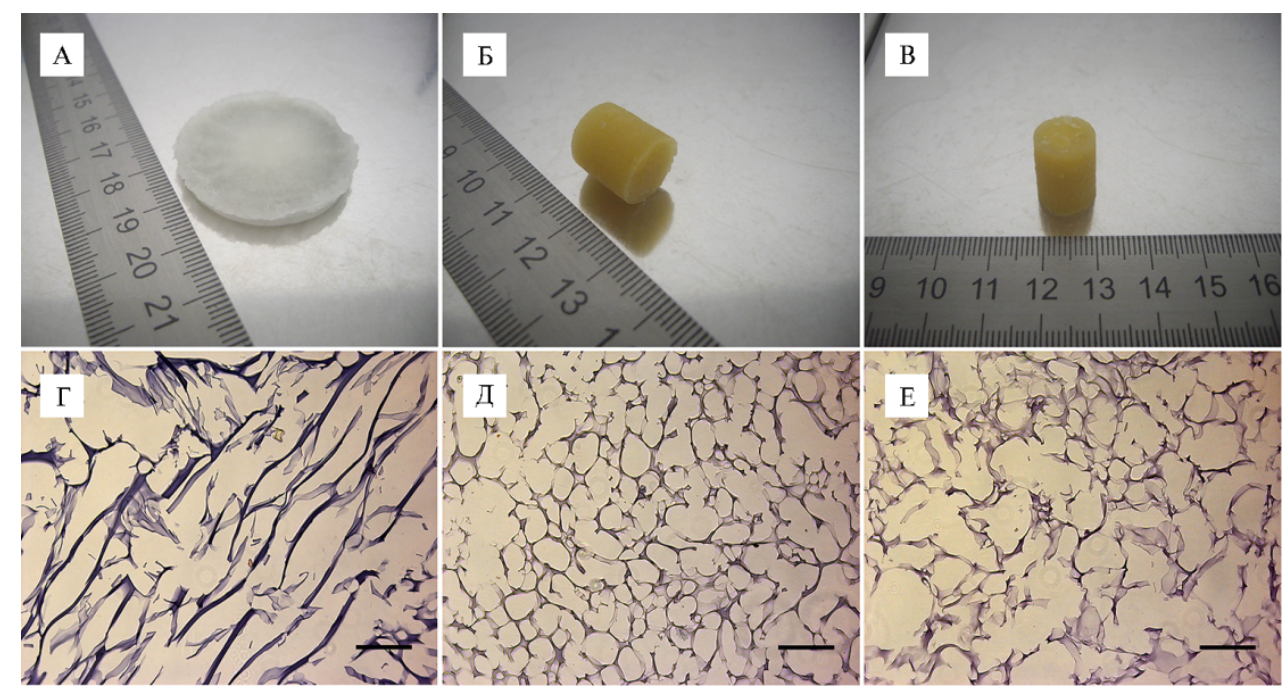

Рис. 1. Макро- и микроструктура губчатых криогелей на основе желатина (А, Г), белков плазмы крови крупного рогатого скота (Б, Д) и сыворотки крови плодов коров (В, Е). Окраска красителем Гимза, масштабная линейка 500 мкм, микроскоп Axio Observer D.1 («Carl Zeiss», Германия).

В течение 24 ч после заселения ММСК материал белковых носителей не оказывал цитотоксического действия на клетки. Наши наблюдения согласуются с данными, полученными другими авторами $(13,28,30)$.

1. Эффективность заселения мультипотентных мезенхимных стволовых клеток в желатиновые криогели (объем носителя $0,24 \mathrm{~cm}^{3}, 1 / 4$ часть криогеля)

\begin{tabular}{l|c|c}
\hline $\begin{array}{l}\text { Количество } \\
\text { клеток }\end{array}$ & $\begin{array}{c}\text { Объем питатель- } \\
\text { ной среды }\end{array}$ & $\begin{array}{c}\text { Эффективность } \\
\text { заселения, \% }\end{array}$ \\
\hline $5 \times 10^{5}$ & 100 & 87 \\
$5 \times 10^{5}$ & 500 & 76 \\
$1 \times 10^{6}$ & 100 & 98 \\
$1 \times 10^{6}$ & 500 & 86 \\
\hline
\end{tabular}

В результате экспериментального подбора рационального соотношения концентрации клеток и объема среды для их загрузки в криогели были отработаны условия заселения клеток на примере желатиновых матриц (табл. 1). Оптимальным для насыщения желатиновых матриц оказался объ-

ем среды 100 мкл. Оптимум концентрации клеток для заселения клеточной суспензии методом естественного всасывания при набухании отжатых губок объемом $0,24 \mathrm{~cm}^{3}-1,0 \times 10^{6}$ кл/100 мкл среды в течение 2 ч насыщения. Эффективность загрузки ММСК в носители составляла 98 \%. Увеличение объема среды приводило к потере клеточного материала, вероятно, обусловленного избытком жидкой фазы. Ранее для заселения желатиновых криогелей использовался динамический (перфузионный) метод загрузки с высокой эффективностью (30).

Метод заселения клеток заключался в использовании специального устройства, которое представляло собой два сосуда, соединенных гибкой пластиковой трубкой. В один из сосудов помещали пористый носитель, диаметр которого совпадал с внутренним диаметром сосуда, во второй - 
около 100-200 мкл клеточной суспензии $\left(1,3 \times 10^{6}\right.$ кл/мл), после чего посредством поочередных мягких возвратно-поступательных движений поршней цилиндров носитель медленно насыщался клетками с питательной средой. Насыщенный носитель оставляли на 3 ч в сосуде, помещенном в $\mathrm{CO}_{2}$-инкубатор, после чего переносили в лунки планшета, содержащие около 1 мл питательной среды. Для заселения криогелей клетками использовали методику отжатия губки после стерилизации. Носители после отжатия от остатков среды легко и быстро восстанавливали форму за счет эластичности материала, всасывая при этом клеточную суспензию, нанесенную на их верхнюю поверхность. Такой метод загрузки клеток в макропористые губчатые матрицы не уступал по эффективности перфузионному и был прост в исполнении.

Была изучена жизнеспособность клеток внутри указанных губчатых носителей в динамике - на 7-е и 14-е сут культивирования. Результаты анализа гистологического окрашивания срезов (не менее 10 для каждого образца) продемонстрировали способность трехмерных пористых носителей поддерживать клетки в культуре на протяжении 14 сут. Данные подтверждались окрашиванием клеток ФД - гидрофобным нефлуоресцирующим соединением, легко проникающим сквозь клеточную мембрану в клетку, где при участии клеточных эстераз оно подвергается метаболизму с образованием красителя флуоресцеина. Обладающий зеленой флуоресценцией ФД сохраняется только в цитоплазме жизнеспособных клеток, имеющих интактную цитоплазматическую мембрану, поскольку не обладает свойством проникать через поврежденные мембраны.

Сравнительный анализ гистологических срезов трех криогелей показал пригодность как желатиновых, так и полученных из суммарного белка крови КРС и СКПК матриц для культивирования ММСК сельскохозяйственных животных. Губки были заполнены клетками, которые сохраняли морфологию и размножались в местах прикрепления к стенкам макропор (рис. 2).
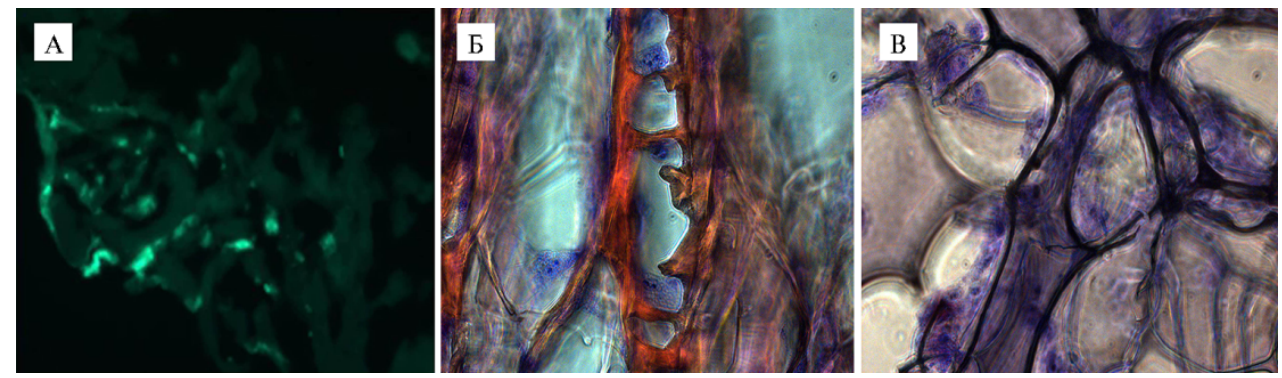

Рис. 2. Микрофотографии срезов широкопористых матриц на основе желатина (А, Б) и белков плазмы крови крупного рогатого скота (КРС) (В), содержащих закрепленные на стенках макропор мультипотентные мезенхимные стволовые клетки из костного мозга КРС, окрашенные флуоресцеинодиацетатом (А) и красителем Гимза (Б, В). Микроскоп Axio Observer D.1 («Carl Zeiss», Германия), увеличение $\times 200$ (А) и $\times 400$ (Б, В).

Результаты экспериментов по влиянию материала матрицы на миграцию клеток приведены на рисунке 3. По данным микроскопии гистологических срезов, все клетки мигрировали из монослоя в объем криогеля с нижней стороны и не обнаруживались на верхних сторонах исследуемых губок. Количество адгезируемых клеток в криогеле увеличивалось при культивировании. Так, на 10-е сут было выявлено распространение фибробластов линии STO в объеме носителей на основе желатина, белка плазмы крови и СКПК на расстояние соответственно 2990, 2871 и 1930 мКм (см. рис. 3, А, Б, В). ММСК, выделенные из ЖТ КРС, мигрировали 
вглубь пористой структуры губчатых матриц на 607, 1364 и 657 мкм (см. рис. 3, Г, Д, Е). Распространение ММСК, выделенных из КМ КРС и овец, в криогелях на основе разных материалов существенно не отличалось от миграции ММСК ЖТ. Сравнительный анализ полученных результатов в трех повторных экспериментах продемонстрировал, что губчатые криогелевые носители на основе желатина, белков плазмы крови КРС и СКПК поддерживали жизнеспособность ММСК в течение краткосрочного культивирования, способствовали клеточной адгезии, пролиферации и миграции. Структура этих криогелей оказалась биосовместимой как для мышиных фибробластов, так и ММСК сельскохозяйственных животных. Однако иммортализованные фибробласты мыши проявляли значительно более высокую степень адгезивности и миграции при таком методе заселения во всех криогелях.

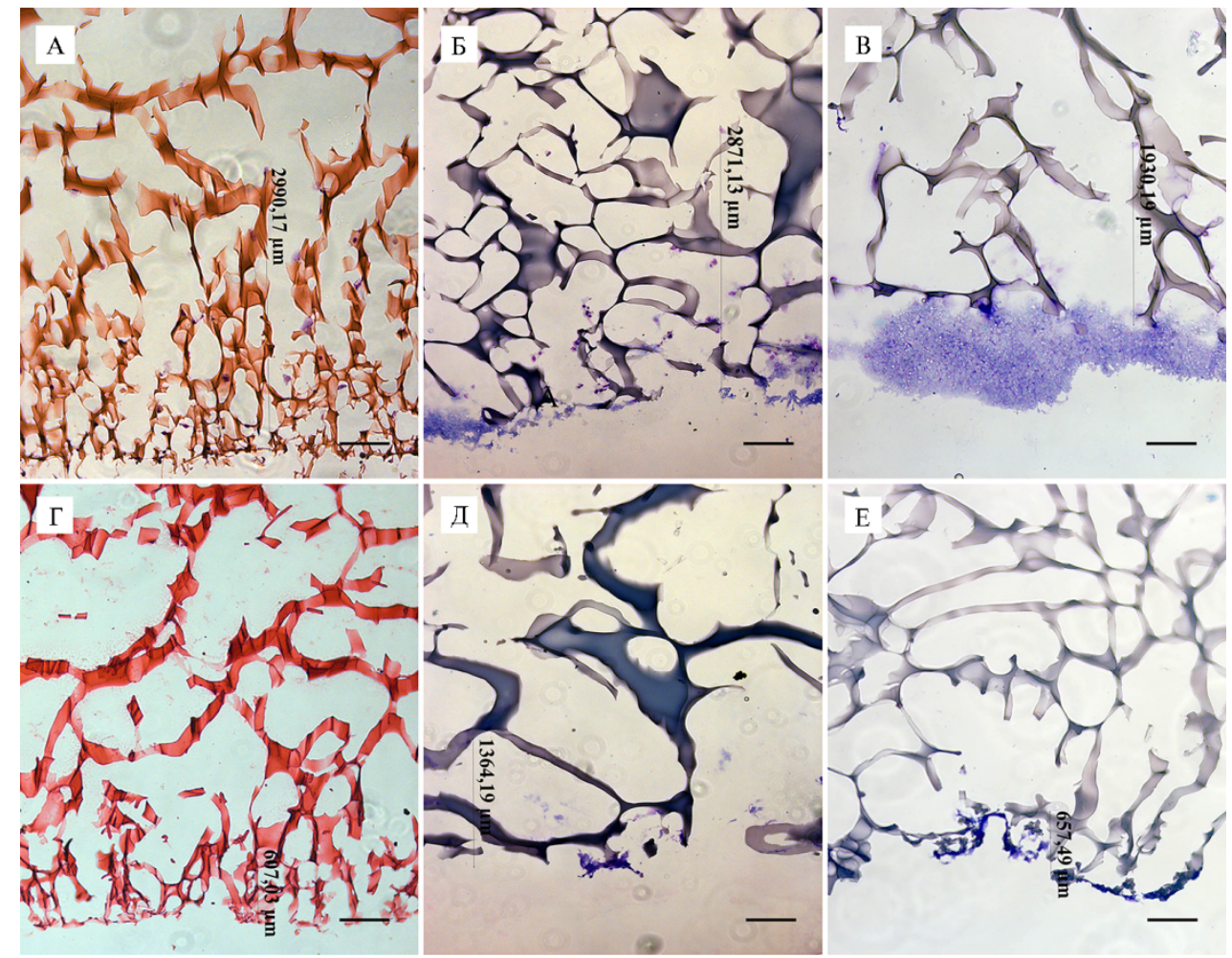

Рис. 3. Глубина распространения клеток в объеме носителей на 10-е сут культивирования: фибробласты STO в матрицах на основе желатина (А), белка плазмы крови крупного рогатого скота (КРС) (Б), сыворотки крови плодов коров (СКПК) (В); мультипотентные мезенхимные стволовые клетки, полученные из жировой ткани, в матрицах на основе желатина $(Г)$, белка плазмы крови КРС (Д), СКПК (Е). Окраска гематоксилином и эозином (А, Г) и красителем Гимза (Б, В, Д, Е), масштабная линейка 500 мкм, микроскоп Axio Observer D.1 («Carl Zeiss», Германия).

Ранее мы показали влияние длительного культивирования ММСК, выделенных из ЖТ человека, на эффективность адгезии клеток к белкам ВКМ. Клетки на 2-м и 17-м пассажах культивирования различались по способности прикрепляться к поверхности с предварительно нанесенными белками BКМ: фибронектину, коллагену и ламинину. Прикрепленные к фибронектину и коллагену клетки на 2-м пассаже по числу превосходили таковых на 17-м пассаже соответственно в 2 и 5 раз. При этом количество адгезирующих к ламинину клеток на 17-м пассаже было в 2 раза выше по сравнению с клетками на 2-м пассаже (31). 
Представляло интерес сравнить ММСК КРС и овцы на ранних и поздних пассажах по способности адгезии к исследуемым матриксам. Для этого на поверхность криогелей наслаивали $1 \times 10^{6}$ кл/100 мкл среды. Адгезия клеток на ранних и поздних пассажах культивирования в макропористых криогелях существенно не различалась (табл. 2). Это свидетельствует о сохранении адгезивных свойств ММСК КРС и овцы в процессе культивирования.

2. Влияние ранних и поздних пассажей мультипотентных мезенхимных стволовых клеток крупного рогатого скота (ММСК КРС) и овцы на адгезию к носителям $(M \pm \mathrm{SEM}, n=3)$

\begin{tabular}{l|c|c|c}
\hline \multirow{2}{*}{ Источник ММСК } & \multirow{2}{*}{ Пассаж } & \multicolumn{2}{|c}{ Количество клеток, прикрепленных к криогелям, $\times 10^{5}$} \\
\cline { 3 - 4 } Жировая ткань КРС & 2 -й & $8,0 \pm 0,10$ & $7,8 \pm 0,13$ \\
& 9 -й & $7,5 \pm 0,30$ & $7,9 \pm 0,10$ \\
Костный мозг КРС & 2 -й & $9,0 \pm 0,20$ & $8,5 \pm 0,70$ \\
& $10-и ̆$ & $8,7 \pm 0,01$ & $8,5 \pm 0,23$ \\
Костный мозг овцы & $3-и ̆$ & $7,2 \pm 0,17$ & $7,0 \pm 0,50$ \\
& $10-и ̆$ & $6,9 \pm 0,70$ & $7,1 \pm 0,12$ \\
\hline
\end{tabular}

Анализ научной литературы показал, что желатиновые криогели применяются для культивирования первичных кератиноцитов и фибробластов человека (31). На поверхности полученных губчатых подложек in vitro они формировали сплошной слой эпителия. Выявлено, что фибробласты способны легко мигрировать вглубь пористой структуры этих носителей. Доклинические испытания с использованием свиней демонстрировали биосовместимость желатиновых криогелей, их нетоксичность для организма животных. Имеются данные о добавлении к желатину других компонентов, которые повышают прочность желатиновых криогелей, например введении в исходный состав хитозана, который способствует поддержанию клеточной адгезии и пролиферации (32-35).

ММСК рассматривают как перспективный клеточный материал для регенерации суставов и связок у животных $(1,2)$. Имплантирование клеточных препаратов на основе пористых биоразлагаемых матриц относится к одному из способов введения клеток в организм. Криогели на белковой основе применяют в качестве пористых подложек для объемного культивирования ММСК и последующей имплантации полученных образцов той или иной ткани благодаря их макропористой морфологии и способности к биодеградации $(4,9)$. Имеются данные о применении для этой цели разных криогелей на основе желатина (17), сывороточного альбумина (21) и суммарного белка сыворотки крови (18-20). Представляло интерес протестировать криогели в связи с разработкой в нашей лаборатории метода создания «культурального мяса в пробирке» (10). Для этого был использован ряд белковых криогелей, которые применяли в качестве подложек для трехмерного культивирования ММСК, выделенных из КМ и ЖТ КРС и овцы. Полученные нами результаты позволяют предположить, что сыворотка (плазма) крови КРС включает в себя факторы, усиливающие адгезию и пролиферацию ММСК. В результате криотропного образования гелей белками плазмы крови такие компоненты встраиваются в матрицу формируемых криогелей, которые в сравнении с носителями на основе альбумина создают более благоприятные условия для культивирования стволовых клеток (19).

Таким образом, в настоящее время методы клеточной биологии, в том числе трехмерное культивирование клеток млекопитающих, приобрели приоритетное значение для исследовательских и прикладных целей в различных областях науки и техники. Мы показали, что использование 
криогелей на основе желатина и белков плазмы крови крупного рогатого скота и сыворотки крови плодов коров позволяет адаптировать адгезивную культуру мультипотентных мезенхимных стволовых клеток (ММСК) крупного рогатого скота и овцы к суспензионному культивированию в биореакторе. Полученные нами данные позволяют прогнозировать применение этих криогелей в качестве матриц для крупномаштабных технологий выращивания ММСК сельскохозяйственных животных.

\section{ЛИТЕРАТУРА}

1. Савченкова И.П., Гулюкин М.И. Перспективы использования стволовых клеток в ветеринарии. Ветеринария, 2011, 7: 3-5.

2. Роговая О.С., Краснов М.С., Косовская Е.В., Косовский Г.Ю. Мезенхимные стволовые клетки как иммуносупрессоры в клеточной терапии. Сельскохозяйственная биология, 2011, 2: 15-20.

3. Panchalingam K.M., Jung S., Rosenberg L., Behie L.A. Bioprocessing strategies for the largescale production of human mesenchymal stem cells: a review. Stem Cell Res. Ther., 2015, 6: 225 (doi: 10.1186/s13287-015-0228-5).

4. Tavassoli H., Alhosseini S.N., Tay A., Chan P.P.Y., Weng Oh S.K., Warkiani M.E. Largescale production of stem cells utilizing microcarriers: A biomaterials engineering perspective from academic research to commercialized products. Biomaterials, 2018, 181: 333-346 (doi: 10.1016/j.biomaterials.2018.07.016).

5. Grein T.A., Leber J., Blumenstock M., Petry F., Weidner T., Salzig D., Czermak P. Multiphase mixing characteristics in a microcarrier-based stirred tank bioreactor suitable for human mesenchymal stem cell expansion. Process Biochemistry, 2016, 51(9): 1109-1119 (doi: 10.1016/j.procbio.2016.05.010).

6. Moloudi R., Oh S., Yang C., Teo K.L., Lam A.T-L., Warkiani M.E., Naing M.W. Inertialbased filtration method for removal of microcarriers from mesenchymal stem cell suspensions. Scientific Reports, 2018, 8: 12481 (doi: 10.1038/s41598-018-31019-y).

7. Rafiq Q.A., Ruck S., Hanga M.P., Heathman T.R.J., Coopman K., Nienow A.W., Williams D.J., Hewitt C.J. Qualitative and quantitative demonstration of bead-to-bead transfer with bone marrowderived human mesenchymal stem cells on microcarriers: utilising the phenomenon to improve culture performance. Biochemical Engineering Journal, 2018, 135: 11-21 (doi: 10.1016/j.bej.2017.11.005).

8. Nienow A.W., Hewitt C.J., Heathman T.R.J., Glyn V.A.M., Fonte G.N., Hanga M.P., Coopman K., Rafiq Q.A. Agitation conditions for the culture and detachment of hMSCs from microcarriers in multiple bioreactor platforms. Biochemical Engineering Journal, 2016, 108: 24-29 (doi: 10.1016/j.bej.2015.08.003).

9. Li B., Wang X., Wang Y., Gou W., Yuan X., Peng J., Guo Q., Lu S. Past, present, and future of microcarrier-based tissue engineering. Journal of Orthopaedic Translation, 2015, 3(2): 51-57 (doi: 10.1016/j.jot.2015.02.003).

10. Volkova I.M., Korovina D.G. Three-dimensional matrixes of natural and synthesic origin for cell biotechnology. Applied Biochemistry and Microbiology, 2015, 51(9): 841-856 (doi: 10.1134/S0003683815090082).

11. Лозинский В.И. Криогели на основе природных и синтетических полимеров: получение, свойства и области применения. Успехи химии, 2002, 71(6): 559-585 (doi: 10.1070/RC2002v071n06ABEH000720).

12. Lozinsky V.I. Polymeric cryogels as a new family of macroporous and supermacroporous materials for biotechnological purposes. Russ. Chem. Bull., 2008, 57(5): 1015-1032 (doi: 10.1007/s11172008-0131-7).

13. Тихвинская О.А., Рогульская Е.Ю., Волкова Н.А., Грищук В.П., Ревенко Е.Б., Мазур С.П., Лозинский В.И., Петренко Ю.А., Петренко А.Ю. Макропористые носители на основе плазмы крови как биосовместимые покрытия для восстановления полнослойных эксцизионных ран. Проблеми кріобіології $i$ кріомедицини, 2018, 28(1): 044-048 (doi: 10.15407/cryo28.01.044).

14. Geckil H., Xu F., Zhang X., Moon S., Demirci U. Engineering hydrogels as extracellular matrix mimics. Nanomedicine, 2010, 5(3): 469-484 (doi: 10.2217/nnm.10.12).

15. Katsen-Globa F., Meiser I., Petrenko Y.A., Ivanov R.V., Lozinsky V.I., Zimmermann H., Petrenko A.Y. Towards ready-to-use 3-D scaffolds for regenerative medicine: adhesion-based cryopreservation of human mesenchymal stem cells attached and spread within alginate-gelatin cryogel scaffolds. J. Mater. Sci.: Mater. Med., 2014, 25(3): 857-871 (doi: 10.1007/s10856-013-5108-x).

16. Afewerki S., Sheikhi A., Kannan S., Ahadian S., Khademhosseini A. Gelatin-polysaccharide composite scaffolds for 3D cell culture and tissue engineering: towards natural therapeutics. Bioengineering \& Translational Medicine, 2019, 4(1): 96-115 (doi: 10.1002/btm2.10124). 
17. Ghaderi Gandomani M., Sahebghadam Lotfi A., Kordi Tamandani D., Arjmand S., Alizadeh S. The enhancement of differentiating adipose derived mesenchymal stem cells toward hepatocyte like cells using gelatin cryogel scaffold. Biochemical and Biophysical Research Communications, 2017, 491(4): 1000-1006 (doi: 10.1016/j.bbrc.2017.07.167).

18. Ferrero-Gutierrez A., Menendez-Menendez Y., Alvarez-Viejo M., Meana A., Otero J. New serum-derived albumin scaffold seeded with adipose-derived stem cells and olfactory ensheathing cells used to treat spinal cord injured rats. Histol. Histopathol., 2013, 28(1): 89-100 (doi: 10.14670/HH-28.89).

19. Gallego L., Junquera L., Meana A., Alvarez-Viejo M., Fresno M. Ectopic bone formation from mandibular osteoblasts cultured in a novel human serum-derived albumin scaffold. Journal of Biomaterials Applications, 2010, 25(4): 367-381 (doi: 10.1177/0885328209353643).

20. Peña G.I., Álvarez-Viejo M., Alonso-Montes C., Menéndez-Menéndez Y., Gutiérrez Á.F., de Vicente Rodríguez J.C., Otero Hernández J., Meana Infiestae Á. Regeneration of mandibular defects using adipose tissue mesenchymal stromal cells in combination with human serum-derived scaffolds. Journal of Cranio-Maxillofacial Surgery, 2016, 44(9): 1356-1365 (doi: 10.1016/j.jcms.2016.06.012).

21. Gallego L., Junquera L., García E., García V., Álvarez-Viejo M., Costilla S., Fresno M.F., Meana Á. Repair of rat mandibular bone defects by alveolar osteoblasts in a novel plasma-derived albumin scaffold. Tissue Engineering Part A, 2010, 16(4): 1179-1187 (doi: 10.1089/ten.TEA.2009.0517).

22. Elowsson L., Kirsebom H., Carmignac V., Mattiasson B., Durbeej M. Evaluation of macroporous blood and plasma scaffolds for skeletal muscle tissue engineering. Biomaterials Science, 2013, 4: 402-410 (doi: 10.1039/C2BM00054G).

23. Tibbitt M.W., Anseth K.S. Hydrogels as extracellular matrix mimics for 3D cell culture. Biotechnol. Bioeng., 2009, 103(4): 655-663 (doi: 10.1002/bit.22361).

24. Волкова И.М., Викторова Е.В., Савченкова И.П., Гулюкин М.И. Характеристика мезенхимных стволовых клеток, выделенных из костного мозга и жировой ткани крупного рогатого скота. Сельскохозяйственная биология, 2012, 2: 32-38 (doi: 10.15389/agrobiology.2012.2.32rus).

25. Коровина Д.Г., Волкова И.М., Васильева С.А., Гулюкин М.И., Савченкова И.П. Мультипотентные мезенхимные стволовые клетки, выделенные из костного мозга овцы: получение и криоконсервирование. Цитология, 2019, 61(1): 35-44 (doi: 10.1134/S0041377119010036).

26. Lozinsky V.I., Kulakova V.K., Ivanov R.V., Petrenko A.Y., Rogulska O.Y., Petrenko Y.A. Cryostructuring of polymer systems. 47. Preparation of wide porous gelatin-based cryostructurates in sterilizing organic media and assessment of the suitability of thus formed matrices as spongy scaffolds for 3D cell culturing. e-Polymers, 2018, 18(2): 175-186 (doi: 10.1515/epoly-2017-0151).

27. Лозинский В.И., Константинова Н.Р., Соловьева Н.И. Способ получения пористого белкового геля. МПК А23Ј 3/00. Институт пищевых веществ РАН (РФ). № 2058083. Заявл. 24.02.1994. Опубл. 20.04.1996. Бюл. № 11.

28. Родионов И.А. Криогели на основе сывороточного альбумина: синтез, свойства, структура и возможности биомедицинского применения. Канд. дис. М., 2017.

29. Пирс Э. Гистохимия: Теоретическая и прикладная. М., 1962.

30. Петренко Ю.А., Иванов Р.В., Лозинский В.И., Петренко А.Ю. Сравнительное исследование методов заселения широкопористых носителей на основе альгинатного криогеля мезенхимальными стромальными клетками костного мозга человека. Kлеточные технологии в биологии и медицине, 2010, 4: 225-228.

31. Савченкова И.П., Савченкова Е.А., Гулюкин М.И. Изменения мультипотентных мезенхимных стромальных клеток, выделенных из подкожно-жировой ткани человека, в результате длительного культивирования. Цитология, 2017, 59(5): 307-314 (doi: 10.1134/S1990519X17050066).

32. Allan I.U., Tolhurst B.A., Shevchenko R.V., Dainiak M.B., Illsley M., Ivanov A., Jungvid H., Galaev I.Y., James S.L., Mikhalovsky S.V., James S.E. An in vitro evaluation of fibrinogen and gelatin containing cryogels as dermal regeneration scaffolds. Biomaterials Science, 2016, 4(6): 1007-1014 (doi: 10.1039/c6bm00133e).

33. Chen C.H., Kuo C.Y., Wang Y.J., Chen J.P. Dual function of glucosamine in gelatin/hyaluronic acid cryogel to modulate scaffold mechanical properties and to maintain chondrogenic phenotype for cartilage tissue engineering. Int. J. Mol. Sci., 2016, 17(11): 1957 (doi: 10.3390/ijms17111957).

34. Wahl E.A., Fierro F.A., Peavy T.R., Hopfner U., Dye J.F., Machens H.G., Egaña J.T., Schenck T.L. In vitro evaluation of scaffolds for the delivery of mesenchymal stem cells to wounds. BioMed Research International, 2015, 2015: 108571 (doi: 10.1155/2015/108571).

35. Kang B.J., Kim Y., Lee S.H., Kim W.H., Woo H.M., Kweon O.K. Collagen I gel promotes homogenous osteogenic differentiation of adipose tissue-derived mesenchymal stem cells in serum-derived albumin scaffold. Journal of Biomaterials Science, Polymer Edition, 2013, 24(10): 1233-1243 (doi: 10.1080/09205063.2012.745717).

1ФГБНУ ФНЦ Всероссийский НИИ экспериментальной ветеринарии им. Я.Р. Коваленко РАН,

109428 Россия, г. Москва, Рязанский пр., 24, корп. 1,

e-mail: darya.korovina@gmail.com $\bowtie$, staffvicky@mail.ru, plych@mail.ru,
Поступила в редакцию 2 августа 2019 года 


\title{
MAINTENANCE OF MULTIPOTENT MESENCHYMAL STEM CELLS OF FARM ANIMALS IN CRYOGELS BASED ON NATURALLY- DERIVED POLYMERS
}

\author{
D.G. Korovina ${ }^{1}$, V.V. Stafford ${ }^{1}$, A.M. Gulyukin ${ }^{1}$, I.A. Rodionov' ${ }^{2}$ K.V. Kulakova ${ }^{2}$, \\ V.I. Lozinsky², I.P. Savchenkoval
}

\author{
${ }^{1}$ Federal Science Center Kovalenko All-Russian Research Institute of Experimental Veterinary RAS, 24/1, Ryazanskii \\ pr., Moscow, 109428 Russia, e-mail darya.korovina@gmail.com ( $₫$ corresponding author), staffvicky@mail.ru, \\ plych@mail.ru, s-ip@mail.ru; \\ ${ }_{2}^{2}$ Nesmeyanov Institute of Organoelement Compounds RAS, 28, ul. Vavilova, Moscow, 119334 Russia, e-mail ilyarodi- \\ onov2@gmail.com, valkirkul@mail.ru, loz@ineos.ac.ru \\ ORCID: \\ Korovina D.G. orcid.org/0000-0003-2186-6084 \\ Stafford V.V. orcid.org/0000-0001-8725-2320 \\ Gulyukin A.M. orcid.org/0000-0003-2160-4770 \\ Kulakova K.V. orcid.org/0000-0003-3090-2999 \\ Lozinsky V.I. orcid.org/0000-0002-8111-1161 \\ Rodionov I.A. orcid.org/0000-0001-8821-2152 \\ Savchenkova I.P. orcid.org/0000-0003-3560-5045 \\ The authors declare no conflict of interests \\ Acknowledgements: \\ This work was performed as part of research work No. 0578-2018-0006 "Creation of new cell systems with desired \\ properties based on mammalian stem cells, including farm animals for veterinary medicine, virology and biotech- \\ nology". \\ Received August 2, 2019 \\ doi: 10.15389/agrobiology.2019.6.1214eng
}

\begin{abstract}
Multipotent mesenchymal stem cells (MMSCs) of farm animals, whose growth in culture is determined by attachment to a solid substrate, are promising cellular material for veterinary medicine and biotechnology, as well as virology. One of the methods to overcome cell adhesion in suspension bioreactors in order to obtain a large number of cells with permanent properties of acceptable quality is the use of porous carriers formed from polymers of natural origin. Thus, for the first time we obtained data that allow us to make a scientific substantiation of the parameters for the cultivation of adhesive cultures of animal MMSCs using spatial protein-based cryogel carriers for subsequent suspension cultivation of the obtained constructs. The purpose of the work is to study the possibility to culture MMSC of farm animals in three-dimensional matrix sponges, i.e. the cryogels based on gelatin, blood plasma total protein and fetal bovine serum (FBS). MMSCs isolated from bovine bone marrow (BM) and adipose tissue (AT) and ovine BM, as well as mouse fibroblast STO cell line were used. We found that the optimal cell concentration for the settlement of the cell suspension by the method of natural absorption with swelling of squeezed sponges $\left(0.24 \mathrm{~cm}^{3}\right.$ in volume $)$ is $1.0 \times 10^{6}$ cells per $100 \mu \mathrm{l}$ of medium for $2 \mathrm{hrs}$ of saturation. The loading efficiency of MMSCs in sponge scaffolds is $98 \%$. The analysis of histological slices (at least 10 per sample) of three cryogels demonstrated the ability of all three-dimensional porous scaffolds to maintain cell culture for 14 days. Sponges were filled with cells that preserved morphology and proliferated in places of attachment to the polymer surface. The results of experiments on the effect of the matrix material on cell migration showed that all cells migrate from the monolayer in the volume of cryogel from the bottom and are not detected on the upper sides of the cryogels under study. On day 10 of culture, fibroblast STO cell line were detected in the volume of sponge scaffolds based on gelatin, blood plasma and FBS protein at a distance of 2990, 2871 and $1930 \mu \mathrm{m}$, respectively. MMSCs isolated from bovine AT migrated into the porous structure of matrix sponges to a depth of 607,1364 and $657 \mu \mathrm{m}$, respectively. Expansion of MMSCs isolated from bovine and ovine BM in cryogels on the basis of different materials did not differ significantly from the migration of AT-MMSCs. The ability of farm animals' MMSCs on the early passages ( 2 to 3 ) and late passages ( 9 to 10 ) to attach to macroporous cryogels was not significantly different. Comparative analysis of the results of the experiments obtained in three replicates showed that the macroporous matrices based on gelatin, bovine blood plasma proteins and FBS support the viability of MMSCs during short-term culture, promote cellular adhesion, proliferation and migration. The obtained data allow us to predict the use of these cryogels as matrices for MMSCs of farm animals for research and practical use.
\end{abstract}

Keywords: multipotent mesenchymal stem cells, adipose tissue, bone marrow, farm animals, adhesion, migration, viability, cryogels, gelatin, bovine protein of blood plasma and serumderived scaffolds. 